\title{
Lipase and their different industrial applications: A review
}

\section{Ritika Joshi and Arindam Kuila*}

Department of Bioscience and Biotechnology, Banasthali Vidyapith, Rajasthan304022, India.*Email: arindammcb@gmail.com.

\begin{abstract}
Enzymes are also known natural catalysts. Lipases are flexible enzymes that are mostly used. These enzymes are found extensively all over the animal and plant kingdoms, likewise in molds and bacteria. Among all identified enzymes, lipases have concerned the mainly biotechnological attention. This review paper discusses the characteristic, microbial origin and application of lipases. The present review discussed about different characteristics and sources (fungal, bacteria's) of lipase. The present article also discussed about different bioreactors used for lipase production and different biotechnological applications (food, detergent, paper and pulp, biofuels etc) of lipases. An observation to considerate lipases and their applications as bulk enzymes and high-value of production, these enzymes are having huge impact in different bioprocesses.
\end{abstract}

Keywords: Lipase; Microbial source; Bioreactors; Industrial application.

\section{Introduction}

The interest for biotechnological enzymes, especially from microbial origin, is constantly growing due to their applications in a broad diversity of processes. Lipases are a central group of biotechnologically applicable enzymes and they find enormous applications in detergent, pharmaceutical food and dairy industries.

Lipases

(triacylglycerol acylhydrolases EC: 3.1.1.3) are produced from a variety of living organisms such as
Received

June 26, 2018

Accepted

August 11, 2018

Released

August 31, 2018

Full Text Article

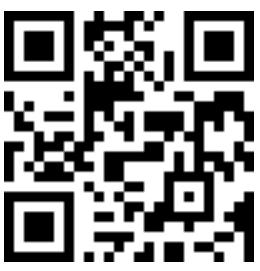

ORCID

ㄴ) 0000-0003-2177-9191

Ritika Joshi

(1) 0000-0002-5913-0307

Arindam Kuila plants, animals, bacteria, fungi, yeasts, actinomycetes. Amongst all, microbial sources of lipase have gained industrial attention in past few years because of unique properties and chemical stability (Abada, 2008).

\section{General characteristics of lipase}

Lipase is a pervasive enzyme which is essential for physiological importance and industrial uses. Lipases accelerate the breakdown of triglycerides to glycerol and free fatty 
acids. In addition, lipase causes the breakdown and transesterification esters at the same time, synthesis of esters also take place (Thakur, 2012).

They are dissolved in water and unable to dissolve in polar lipolytic. In 1856, the 1st lipolytic enzyme was discovered by Claude Bernard and after that it was recognized from animals, plant and microorganism (fungus, bacteria and yeast).

\section{Lipase catalyzed reaction}

Lipases are the most pliant biocatalyst and convey broad series of biotransformation reactions, i.e., hydrolysis, esterification, interesterification, aminolysis, alcoholysis and acidolysis (Kumar and Gupta, 2008).

In inclusion, lipase has longestablished ability to stimulate breakdown of lipid, they can also stimulate synthetic reactions, for example transesterification (Shariff et al., 2007). Lipase catalyzed reactions into three most important classes according to previous report (Devi et al., 2012):

(i) Hydrolysis: this reaction occurs in the presence of high amount of water, where breakdown of ester bond take place. This technique is currently used in the formation of fatty acids, monoglycerides, diglycerides, flavouring substance for detergents and dairy products.

(ii) Esterification: It happens under little aqueous environment (anhydrous solvents). High quantity of the products (esterified compounds) is achieved under regulated environment. Formation of Primary (oleic acid esters) and Secondary (aliphatic and terpenic) are most common example (Macrae and Hammond, 1985).

(iii) Transesterification: It includes the exchange of acid moiety between two or more compounds. According to the type of substrates, lipases are able to catalyze acidolysis (it involve ester and carboxylic acid), alcoholysis (it involve ester and an alcohol), aminolysis (ester is allowed to react with an amine) and interesterification (where two acyl groups are exchanged between two esters) (Bajpai and Tyagi, 2007).

\section{Lipase properties}

Since 1980s, the number of obtainable lipase has been increased and used as biocatalysts in industries because of their different properties like $\mathrm{pH}$ dependency, high catalytic state, temperature, bio-degradability and high specificity (Masse et al., 2001). Amyl, isoamyl, isobutyl and ethyl are mostly used as flavor ester (Vaseghi and Najafpour, 2014). Lipase investigated in two sources hydrolytic and synthetic activity. Lipase has ability to consume mono-, di-, triglycerides and free fatty acids which is the most preferred characteristics (Klibanov, 1997). On the other hand, in mild condition of $\mathrm{pH}$ and temperature reaction of lipases is carried out and in abnormal temperatures and pressures energy is reduced for direct reactions. Due to this, unbalanced products and reactants are confined from destruction. Other reasons of lipases are they can be activated without any cofactor and stability in organic solvent (Houde et al., 2004).

\section{Occurrence of lipase}

The microbial origin of lipase is characterized as the most widely used group of enzyme in organic chemistry and biotechnology. Table 1 showed list of different microbes for lipase production. These enzymes are generally found throughout the plant and animal kingdoms, besides in bacteria and mold (Hiol et al., 1999). Lipase enzymes are found in both prokaryotes (Archaea and Bacteria) as well as in eukaryotes (plant, animal and fungi). Lipase of the microbial origin and animal are used widely. Lipase produce from pig pancreas contain trypsin which is a bitter tasting amino acid therefore, due to above mentioned reason, microbes are the preferred choice for the production of 100 or so industries (Jaeger and Reetz, 1998) 
Although many micro organism are recognized as potent producers of extracellular lipase including fungi, yeast and bacteria.

Table 1. List of different microorganisms for lipase production.

\begin{tabular}{llll}
\hline & Microorganism & Source & Reference \\
\hline 1. & P. fluorescens & Bacterium & Pandey et al. (1999) \\
2. & P. pseudomallei & Bacterium & Kanwar and Goswami (2002) \\
3. & Staphylococcus aureus & Bacterium & Simons et al. (1996) \\
4. & P. luteola & Bacterium & Arpigny and Jaeger (1999) \\
5. & Rhizopus sp. & Fungus & Thakur (2012) \\
6. & Pencillium sp. & Fungus & Shelatkar and Padalia (2016) \\
7. & Geotricum sp. & Fungus & Thakur (2012) \\
8. & Aspergillus sp. & Fungus & Cihangir and Sarikaya (2004) \\
9. & Candida rugosa & Yeast & Vakhlu and Kour (2006) \\
10. & Yarrowia lipolytica & Yeast & Amaral et al. (2007) \\
11. & Rhodotorula mucilaginosa & Yeast & Kumar and Gupta (2008) \\
12. & C. cylindracea & Yeast & D'Annibale et al. (2006) \\
\hline
\end{tabular}

\section{Bacterial lipase}

In Malaysia, thermostable lipase was reported by strain L2 which was thermophilic bacterium isolated from hot spring. The extracellular lypolytic activity was done by broth and plate assays at $70^{\circ} \mathrm{C}$ after $28 \mathrm{~h}$ (Selvamohan et al., 2012) Bacterial lypolytic enzyme may be membrane bound, intracellular and extracellular. Bacillus clausii which can only grow on simple lipids and glycerol but not on triglycerides long chain are the intracellular lipase. Bacillus sp. can produces both extracellular and intracellular lipases (Sharma et al., 2016).

Among bacterial lipase, those obtained from Bacillus spp. Show attractive features that make them potent candidates for various biotechnology based industries. Bacillus pumilus (Coradi et al., 2013), Bacillus subtilis (Coradi et al., 2013), Bacillus licheniformis (Romo-Sanchez et al., 2010), Bacillus stearothermophilus (Abada, 2008) and Bacillus amyloliquefaciens (Sangiliyandi and Gunasekaran, 1996) are the potential sources of bacterial lipases. Further, Pseudomonas aeruginosa, Pseudomonas sp. (Mirón et al., 2010), Bacillus cepacia (Ogino et al., 2000), Staphylococcus pasteuri (D'Annibale et al., 2006), Burkholderia multivorans (Gopinath et al., 2002) and Staphylococcus caseolyticus (Verma et al., 2012) has also been reported as bacteria lipase producers (Sztajer et al., 1998).

\section{Fungal lipase}

Funguses are commercially used in the production of lipases. Industrial waste, dairy plants, Vegetable oil processing factories and oil seeds or contaminates soil are some common sources of the lipase producing microorganism. The maximum lipolytic activity is shown by Rhizomes species (Sharma et al., 2016). Filamentous fungi are preferred sources of lipase among the rest the lipase producing. micro organism the main producers of lipase are Pencillium sp. (Gupta et al., 2003), Rhizopus sp. (Marlot et al., 1985), Aspergillus sp. (Abrunhosa et al., 2013), Mucor sp. (Gutierrez et al., 1996), Acremonium alcalophilum (Pandey et al., 1999), Candida rugosa (Pereira et al., 2013), Lipomyces starkeyi (Sumita, 2012), Cunninghamella verticillata (Divakar and Manohar, 2007), 
Trichoderma sp. (Clark et al., 1984) and Geotrichum candidum (Buchon et al., 2000).

\section{Yeast lipase}

Candida rugosa is one of the most rapidly used industrially important enzymes due to its high activity in both hydrolysis as well as synthesis phase (Ramos-Sanchez et al., 2015) . In 1985, Candida rugosa is used by Japan for the production of fatty acids from castor bean (Macedo et al., 2003). Earlier it has been reported for use of microbial lipase in the flavoring of milk and creams production (Padilha et al., 2012). Organolephtic has proved that every lipase strains develop a characteristic flavor (Padilha et al., 2012). Saccharomyces, Torulospora, Kluyveromyces, Candida, Pseudozyma, Pischia, Lachancea and Zygosaccharomyces are the lipase producing yeast belong to different genera (Rajendran et al., 2008).

\section{Different bioreactor used in lipase production}

\section{Tray bioreactors (TB)}

Tray bioreactors made up of a chamber where controlled air (cabin temperature, cabin flow, and cabin humidity) is distributed in different trays. Every tray combines a solid substrate layer, usually between 5 and $15 \mathrm{~cm}$ deep. These trays are generally open from the top and have holes in the bottom which support exchange of gases. With the help of hand steady mixing of the solid substrate could be carried out but it can be only perform once in a day (Menoncin et al., 2008). The drawback of tray bioreactors is their small volumetric efficiency in compare to column bioreactor. In the recent years, there is no significant use of tray design.

\section{Packed-bed bioreactor (PBB)}

Packed-bed bioreactor frequently have a static bed on top have holed plate from which conditioned air is blasted. In other packed -bed bioreactor design, air is blow through a hole rod placed in between of the bed. In last 25 years, PBB has get more modeling and experimental consideration. The most unique characteristic of PBB is that it has no moving parts (mechanical) hence it reduces the cost of maintenance, operation and construction. Axial dynamic temperature is observed in PBB processes (Aruna and Khan, 2014). Since, when the temperature the water carrying quantity of the air will increases, it provide the slope to rise evaporation inside the bed so when the water thoroughly soaked in the air is worn to aerate the column. Although, in cellular metabolism $65 \%$ of the heat produced is remove up by evaporation phenomenon, it decreases the moisture content of solid substrate as a result cellular growth is limited (Gutarra et al., 2009). In PBB, bed is not mixed due improper moisture regulation. Consequently, water jacket is the most advantageous to enhance heat removal.

The large-scale production are very less in grams of solids supports and insufficient in demands studied in recent reports (Berglund and Hutt, 2000). The production of lipase in various bioreactors design is noteworthy and yield is very low at small scale.

\section{Applications of lipases}

Lipase are broadly used in the different application like detergent making, detergents formulations, the synthesis of fine chemicals, food processing, cosmetics, bioremediation processes, pharmaceuticals, and paper manufacture (Verma and Kanwar, 2008). Lipase can be used to speed up the polyurethane and humiliation of fatty waste (Martinez-Ruiz et al., 2008). Table 2 showed different industrial 
applications of lipase. From fungi and bacteria mostly microbial lipases are produced.

\section{Lipases in food processing}

Oil and fat are main ingredients of food in food processing industry, oil and fat modification is the most important part and it has great demand in green technologies (Gupta et al., 2007). Lipase has ability to enhance the place of fatty acid chains in the glyceride and replace them into new one.
In biotechnology, there are various industrial applications that result there are different biotech products that we are using in daily life at home. In food science application several enzyme exploit in the class of various foods. Lipases have vast application in food industries like in flavor development, EMC technology and cheese ripening (Martinez-Ruiz et al., 2008). It is also used in flavor and fragrance compounds which are addition in food to adjust flavor by synthesis of ester (fatty acids and alcohols) (Redondo et al., 1995).

Table 2 Industrial application of lipase.

\begin{tabular}{|c|c|c|}
\hline Industry & Causes & Application \\
\hline $\begin{array}{l}\text { Bakery food, dairy } \\
\text { food and food } \\
\text { dressing }\end{array}$ & $\begin{array}{l}\text { Flavor improvement, breakdown } \\
\text { (cheese ripening, milk and fat), } \\
\text { alteration of butter fat and Quality } \\
\text { upgrade. }\end{array}$ & $\begin{array}{l}\text { Prolongation phenomenon of } \\
\text { flavoring agent in butter and milk } \\
\text { cheese and mayo whippings and } \\
\text { dressing. }\end{array}$ \\
\hline Wellness food & Transesterification. & Health foods. \\
\hline Cleaner & Minimize biodegradable strains. & Washing of strain from fabrics. \\
\hline Surfactants & $\begin{array}{l}\text { Replace phosphoilpases in the } \\
\text { production of lysophospholipids. }\end{array}$ & $\begin{array}{l}\text { In industrial detergent, carbohydrates } \\
\text { fatty acid esters and polyglycerol used } \\
\text { as stabilizer in food creation i.e., ice } \\
\text { creams. }\end{array}$ \\
\hline Pharmaceutical. & Breakdown of expolyester alcohols. & specialty lipids and digestive aids. \\
\hline Agrochemicals. & Esterification. & Herbicides,i.e. phenoxypropionate. \\
\hline Liquor. & Enhance aroma. & $\begin{array}{l}\text { Undistilled fermented beverages such } \\
\text { as beer, wine. }\end{array}$ \\
\hline Fuel industries. & Transesterification. & Production of biodiesel. \\
\hline Meat and fish. & Flavor development. & Removal of fat. \\
\hline Pollution control. & $\begin{array}{l}\text { breakdown and transesterification } \\
\text { of oils and grease. }\end{array}$ & $\begin{array}{l}\text { Removal of hard stains, } \\
\text { breakdown oil and greases. }\end{array}$ \\
\hline
\end{tabular}

\section{Lipases in detergents}

Enzymes are mostly used for formulation of detergent in developed countries. Different enzymes like protease, lipase, amylase, cellulose etc are used in detergent industries as they can split oil, fat, starch and protein. Due to capability of hydrolysis of fat and lipid, lipase is used in laundry industries and household detergent (Ashley et al., 1999). Laundry detergent instruct flexibility to fabrics, softness, dissolved in water, harsh to skins and eyes and anti staticness that's way it is commonly used in washing machine and becoming more popular.

\section{industry}

\section{Lipases in pulp and paper}

Enormous amount of lignocelluloses biomass is processed every year by the pulp and paper industry. Historically, enzymes are used in the paper industry for limited uses such as modification of raw starch. In pulp technology, application of microbial 
enzymes is highly diverse and numerous opportunities. Pitch known as the insoluble components of wood (mostly waxes, triglycerides), which causes drastic troubles in pulp and paper manufacturing (Houde et al., 2004). Microbial Lipases are worn in removal of pitch since the pulp formed in paper manufacture. Candida rugosa fungal lipase is used in the hydrolysis of $90 \%$ of the wood triglycerides or waxes it is the pitch control method developed by Nippon Paper Industries, Japan.

\section{Lipases in organic synthesis}

In the synthesis of organic chemical the use of lipase is becoming more and more important. Chemo-, region- and stereoselective transformation in large variety can be accelerating by the use of lipase (Kademi et al., 2003). Microbial lipase worn as a catalysts in bulk amount in organic chemistry. The workings of these enzymes are based on hydrophilic - lipophilic interface. Previously it has been discussed about the enantiopure compounds, which are synthesized by the use of lipase (Balcão et al., 1996). These enzymes catalyze the breakdown of water-immiscible triglycerides at water-liquid interface.

In liquid interface, the enzymes accelerate the breakdown of waterimmiscible triglycerides at water. Under these conditions, the direction of lipase catalyzed reaction depends upon the quantity of water in the reaction mixture. The process of transesterification and esterification is depending upon the amount of water. These processes occur when there is petite or no water and when there is excess of water then hydrolysis reaction take place (Kazlauskas and Bornscheuer, 1998). Catalysis of lipase is supercritical solvent based reaction (Thakur, 2012).

\section{Lipase in bio fuels production}

Bio fuels or biodiesels are the ester of long chain of fatty acids and small chain alcohols. Through direct transesterification of vegetable oils and fat with short chain of alcohols (i.e., ethanol and methanol) in the existence of proper catalyst synthesis of biodiesels molecules take place (Amaral et al., 2007).

Transesterification is process similar to breakdown of water but here instead of water, alcohol is employed. In this reaction, displacement of alcohol from an ester to alcohol takes place (Shirazi et al., 1998). In short chain reaction, methanol, alcohols and ethanol are frequently worn; above all, methanol is used regularly due to physicochemical compensation and low cost. This procedure is frequently worn to decrease the thickness of triglycerides, therefore increasing the physical property of renewable oil to perk up engine presentation (Cihangir and Sarikaya, 2004).

\section{Lipases in pollution control}

In biotechnology, lipase is Employment as the new aspect of bioremediation process. From different origins like restaurants and factories lipase can be used to clean up waste of lipid processing. Lipase could be used in both the ways either in situ or ex situ (Padilha et al., 2012). Environmental pollution and industrial is becoming critical more and more due to speedy development. In enzymological remediation, the lipase strains play important role in soil pollution (Lason and Ogonowski, 2010). Lipase shows unique properties in field of cold adaption like active compounds synthesis cold condition, bioremediation in fat contaminated and wastewater treatment in cold condition (Bhargav et al., 2008). At the same time in different regions, where temperature diminish, the competence microorganisms is degrading pollutants like lipids and oil. This enzyme is perfect for bioremediation process because it is active in moderate low temperature (Sztajer et al., 1998). 


\section{Conclusion}

In industrial use of microorganism is still remaining partial by their production in small amounts, low performance in lipase mediated process and their high production costs. Even though lipases have different fascinating vast applications food processing, detergents, pulp and paper industry, organic synthesis and bio fuels production etc. the latest applications are still to be explore and the applications of lipases are expansion rapidly in these industries.

\section{Conflict of interest}

The authors declare that they have no conflict of interest in the publication.

\section{Reference}

Abada, E. A. E.-M. Production and characterization of mesophilic lipase isolated from Bacillus stearothermophilus AB-1. Pakistan Journal of Biological Sciences, v. 11, no. 8, p. 1100-1106, 2008. https://doi.org/10.3923/pjbs.2008.1100.1106

Abrunhosa, L.; Oliveira, F.; Dantas, D.; Gonçalves, C.; Belo, I. Lipase production by Aspergillus ibericus using olive mill waste water. Bioprocess and Biosystems Engineering, v. 36, no. 3, p. 285-291, 2013. https://doi.org/10.1007/s00449-012-0783-4

Amaral, P. F. F.; Almeida, A. P. R.; Peixoto, T.; Rocha, M. H. M.; Coutinho, C. M. A. Beneficial effects of enhanced aeration using perfluorodecalin in Yarrowia lipolytica cultures for lipase production. World Journal of Microbiology and Biotechnology, v. 23, no. 3, p. 339-344, 2007. https://doi.org/10.1007/s11274-006-9229-y

Andualema, B.; Gessesse, A. Microbial lipases and their industrial application: Review. Biotechnology, v. 11, no. 3, p. 100-118, 2012. https://doi.org/10.3923/biotech.2012.100.118

Aruna, K.; Khan, K. Optimization studies on production and activity of lipase obtained from Staphylococcus pasteuri SNA59 isolated from spoilt skin lotion. International Journal of Current Microbiology and Applied Sciences, v. 3, no. 5, p. 326-347,
2014. Available from: <https://www.ijcmas.com/vol-3-5/K.Aruna and Karim Khan.pdf>. Accessed on: May 23, 2018.

Ashley, V. M.; Mitchell, D. A.; Howes, T. Evaluating strategies for overcoming overheating problems during solid state fermentation in packed bed bioreactors. Biochemical Engineering Journal, v. 3, no. 2, p.141-150, 1999. https://doi.org/ 10.1016/s1369-703x(99)00010-8

Bajpai, D.; Tyagi, V. K. Laundry detergents: An overview. Journal of Oleo Science, v. 56, no. 7, p. 327-340, 2007. Available from: https://doi.org/10.5650/jos.56.327

Balcão, V. M.; Paiva, A. L.; Malcata, F. X. Bioreactors with immobilized lipases: state of the art. Enzyme and Microbial Technology, v. 18, no. 6, p. 393-416, 1996. https://doi.org/10.1016/0141-0229(95)00 125-5

Berglund, P.; Hutt, K. Biocatalytic synthesis of enantiopure compounds using lipases. In: Patel, R. N. (Ed.). Stereo-selective biocatalysis. New York: Marcel Dekker, 2000.

Bhargav, S.; Panda, B. P.; Ali, M.; Javed, S. Solid-state fermentation: An overview. Chemical and Biochemical Engineering Quarterly, v. 22, no. 1, p. 49-70, 2008. Available from: <https://hrcak.srce.hr/ 21397>. Accessed on: Apr. 27, 2018.

Buchon, L.; Laurent, P.; Gounot, A. M.; Guespin, M. J. F. Temperature dependence of extracellular enzyme production by psychotrophic and psychrophilic bacteria. Biotechnology Letters, v. 22, p. 1577-1581, 2000.

Burkert, J. F. M.; Maldonado, R. R.; Maugeri, F.; Rodrigues, M. I. Comparison of lipase production by Geotrichum candidum in stirring and airlift fermenters. Journal of Chemical Technology and Biotechnology, v. 80 , no. 1, p. 61-67, 2005. https://doi.org/ 10.1002/jctb.1157

Cihangir, N.; Sarikaya, E. Investigation of lipase production by a new isolated of Aspergillus sp. World Journal of Microbiology \& Biotechnology, v. 20, no. 2, p. 193-197, 2004. https://doi.org/10.1023/ B:WIBI.0000021781.61031.3a

Clark, S. J.; Wagner, L.; Schock, M. D.; Piennaar, P. G. Methyl and ethyl soybean esters as renewable fuels for diesels engines. Journal of the American Oil Chemists 
Society, v. 61, no. 10, p. 1632-1638, 1984. https://doi.org/10.1007/BF02541648

Coradi, G. V.; Visitação, V. L. D., Lima, E. A. D.; Saito, L. Y. T.; Palmier, D. A.; Takita, M. A.; Oliva Neto, P. D.; Lim, V. M. G. D. Comparing submerged and solid-state fermentation of agro-industrial residue for the production and characterization of lipase by Trichoderma harzianum. Annals of Microbiology, v. 63, no. 2, p. 533-540, 2013. https://doi.org/10.1007/s13213-012-0500-1

D’Annibale, A. D.; Sermanni, G. G.; Federici, F.; Petruccioli, M. Olive-oil wastewaters: A promising substrate for microbial lipase production. Bioresource Technology, v. 97, no. 15 , p. 18-33, 2006. https://doi.org/ 10.1016/j.biortech.2005.09.001

Devi, A. S.; Devi, K. C.; Rajendiran, R. Optimization of lipase production using Bacillus subtilis by response surface methodology. International Journal of Agricultural and Biological Engineering, v. 6 , no. 9, p. 840-845, 2012. Disponível em: $<$ http://scholar.waset.org/1307-

6892/16898>. Accessed on: Apr. 24, 2018.

Divakar, S.; Manohar, B. Use of lipase in the industrial production of esters. In: Polaina, J.; MacCabe, A. P. (Eds.). Industrial Enzymes. Verlag: Wiley VCH, 2007. p. 2-18.

Gopinath, S. C. B.; Hilda, A.; Priya, T. L.; Annadurai, G. Purification of lipase from Cunninghamella verticillata and optimization of enzyme activity using response surface methodology. World Journal of Microbiology and Biotechnology, v. 18, no. 5, p. 449-458, 2002. https://doi.org/ 10.1023/A:1015579121800

Gupta, N.; Sahai, V.; Gupta, R. Alkaline lipase from a novel strain Burkholderia multivorans: statistical medium optimization and production in a bioreactor. Process Biochemistry, v. 42, no. 4, p. 518-526, 2007. https://doi.org/10.1016/j.procbio.2006.10.0 06

Gupta, R.; Rathi, P.; Bradoo, S. Lipase mediated upgradation of dietary fats and oils. Critical Reviews in Food Science and Nutrition, v. 43, no. 6, p.635-644, 2003. https://doi.org/10.1080/104086903902511 47

Gutarra, M. L.; Godoy, M. G.; Maugeri, F.; Rodrigues, M. I.; Freire, D. M. G.; Castilho, L. R. Production of an acidic and thermostable lipase of the mesophilic fungus Penicillium simplicissimum by solid-state fermentation.
Bioresource Technology, v. 100, no. 21, p. 5249-5254, 2009. https://doi.org/ 10.1016/j.biortech.2008.08.050

Gutierrez, M.; Amar, S.; Auria, R.; Revah, S.; Torres, E. F. Heat transfer in citric acid production by solid state fermentation. Process Biochemistry, v. 31, no. 4, p. 11-16, $1996 . \quad$ https://doi.org/10.1016/00329592(95)00071-2

Hiol, A.; Jonzo, M. D.; Druet, D.; Comeau, L. C. Production, purification and characterization of an extracellular lipase from Mucor hiemalis f. hiemalis. Enzyme and Microbial Technology, v. 23, no. 1/2, p. 80-87, 1999. https://doi.org/10.1016/S0141-0229(99) 00009-5

Houde, A.; Kademi, A.; Leblanc, D. Lipases and their industrial applications: An overview. Applied Biochemistry and Biotechnology, v. $118, \quad$ no. $1 / 3$, p. $155-170,2004$. https://doi.org/10.1385/ABAB:118:1-3:155

Jaeger, K. E.; Reetz, T. M. Microbial lipases from versatile tools for biotechnology. Trends in Biotechnology, v. 16, no. 9, p. 396-403, 1998. https://doi.org/10.1016/ S0167-7799(98)01195-0

Kademi, A.; Lee, B.; Houde, A. Production of heterologous microbial lipases by yeasts. Indian Journal of Biotechnology, v. 2, p. 346-355, 2003. Available from: <http://nopr.niscair.res.in/bitstream/12345 6789/11332/1/IJBT\%202\%283\%29\%2034 6-355.pdf>. Accessed on: Apr. 27, 2018.

Kazlauskas, R. J.; Bornscheuer, U. T. Biotransformations with lipases. In: Rehm, H. J.; Pihler, G.; Stadler, A.; Kelly, P. J. W. (Ed.). Biotechnology. New York, USA: 1998.

Klibanov, A. M. Why are enzymes less active in organic solvents than in water? Trends in Biotechnology, v. 15, no. 3, p. 97-101, 1997. https://doi.org/10.1016/S0167-7799(97) 01013-5

Kumar, A.; Sharma, P.; Kanwar, S. S. Lipase catalyzed esters syntheses in organic media: A review. International Journal of LifeSciences Scientific Research, p. 11-15, 2012.

Kumar, D.; Kumar, L.; Ngar, S.; Raina, C.; Prashad, R.; Gupta, V. K. Screening, isolation and production of lipase/esterase producing Bacillus sp. strain DVL2 and its potential evaluation in esterification and resolution reaction. Archives of Applied Science Research, v. 4, no. 4, p. 1767-1770, 2012. 
Kumar, S. S.; Gupta, R. An extracellular lipase from Rhodotorula mucilaginosa MSR 54: Medium optimization and enantioselective deacetylation of phenyl ethyl acetate. Process Biochemistry, v. 43, p. 1054-1060, 2008.

Lasoń, E.; Ogonowski, J. Lipase: characterization, applications and methods of immobilization. Scientific Technique, v. 64, no. 2, p. 15-17, 2010. Available from: <https://yadda.icm.edu.pl/baztech/element/ bwmeta1.element.baztech-article-BPP10096-0070/c/Lason_GB.PDF>. Accessed on: Apr. 27, 2018.

Lin, J. F.; Lin, Q.; Li, J.; Fei, Z. A.; Li, X. R.; Xu, H.; Qiao, D. R.; Cao, Y. Bacterial diversity of lipase-producing strains in different soils in southwest of China and characteristics of lipase. African Journal of Microbiology Research, v. 6, no. 16, p. 3797-3806, 2012. $<$ https://academicjournals.org/article/articl e1380810192_Lin\%20et\%20al.pdf>.

Accessed on: Apr. 27, 2018.

Macedo, G. A.; Lozano, M. M. S.; Pastore, G. M. Enzymatic synthesis of short chain citronellyl esters by a new lipase from Rhizopus sp. Electronic Journal of Biotechnology, v. 6, no. 1 , 2003. https://doi.org/10.2225/vol6issue1-fulltext-2

Macrae, A. R.; Hammond, R. C. Present and future applications of lipases. Biotechnology and Genetic Engineering Reviews, v. 3, no. 1, p.193-218, 1985. https://doi.org/ 10.1080/02648725.1985.10647813

Marlot, C.; Langrand, G.; Triantaphylides, C.; Baratti, J. Ester synthesis in organic solvent catalyzed by lipases immobilized on hydrophilic supports. Biotechnology Letters, v. 7, no. 9, p. 647-650, 1985. https://doi.org/10.1007/BF01040202

Martinez-Ruiz, A.; Garcia, H. S.; SaucedoCastaneda, G.; Favela-Torres, E. Organic phase synthesis of ethyl oleate using lipases produced by solid-state fermentation. Applied Biochemistry and Biotechnology, v. $15, \quad$ no. $2 / 3, \quad$ p. $393-401, \quad 2008$. https://doi.org/10.1007/s12010-008-8207-2

Masse, L.; Kennedy, K. J.; Chou, S. P. The effect of an enzymatic pretreatment on the hydrolysis and size reduction of fat particles in slaughterhouse wastewater. Journal of Chemical Technology and Biotechnology, v. 76, no. 6, p. $629-635,2001$. https://doi.org/10.1002/jctb.428
Menoncin, S.; Domingues, N. M.; Freire, D. M. G.; Toniazzo, G.; Cansian, R. L.; Oliveiraet, J. V. Study of the extraction, concentration, and partial characterization of lipases obtained from Penicillium verrucosum using solid-state fermentation of soybean bran. Food Bioprocess Technology, v. 3, no. 4, p. 537544, 2008. https://doi.org/10.1007/s11947008-0104-8

Mirón, J.; Vazquez, J.; Gonzalez, P.; Murado, M. A. Enhancement glucose oxidase production by solid-state fermentation of Aspergillus niger on polyurethane foams using mussel processing wastewaters. Enzyme Microbial Technology, v. 46, no. 1, p. 21-27, 2010. https://doi.org/10.1016/j.enzmictec.2009.0 7.008

Ogino, H.; Nakagawa, S.; Shinya, M. T.; Fujimura, N.; Yasuda, M.; Ishikawa, $\mathrm{H}$. Purification and characterization of organic solvent-stable lipase from organic solventtolerant Pseudomonas aeruginosa LST-03. Journal of Bioscience and Bioengineering, v. $89, \quad$ no. $5, \quad$ p. $451-457, \quad 2000$. https://doi.org/10.1016/S1389-1723(00) 89095-7

Padilha, G. D. S.; Santana, J. C. C.; Alegre, R. M.; Tambourgi, E. B. Extraction of lipase from Burkholderia cepacia by PEG/phosphate ATPs and its biochemical characterization. Brazilian Archives of Biology and Technology, v. 55, n. 1, p. 7-19, 2012. https://doi.org/10.1590/S1516-89132012 000100002

Pandey, A.; Benjamin, S.; Soccol, C. R.; Nigam, P.; Krieger, N.; Soccol, V. T. The realm of microbial lipases in biotechnology. Biotechnology and Applied Biochemistry, v. 29, no. 2, p. 119-131, 1999. https://doi.org/10.1111/j.1470-8744.1999. tb00541.x

Pereira, E. O.; Tsang, A.; McAllister, T. A.; Menass, R. The production and characterization of new active lipase from Acremonium alcalophilum using a plant bioreactor. Biotechnology for Biofuel, 6:111, 2013. https://doi.org/10.1186/17546834-6-111

Rajendran, A.; Palanisamy, A.; Thangavelu, V. Evaluation of medium components by Placket-Burman Statistical Design for lipase production by Candida rugosa and kinetic modeling. Chinese Journal of Biotechnology, v. 24, no. 3, p. 436-44, 2008. 
https://doi.org/10.1016/S1872-2075(08) 60024-2

Ramos-Sanchez, L. B.; Cujilema-Quitio, M. C.; Julian-Ricardo, M. C.; Cordova, J.; Fickers, P. Fungal lipase production by solid-state fermentation. Journal of Bioprocessing \& Biotechniques, 5:2, 2015. https://doi.org/ 10.4172/2155-9821.1000203

Redondo, O.; Herrero, A.; Bello, J. F.; Roig. M. G.; Calvo, M. V.; Plou, F. J.; Burguillo, F. J. Comparative kinetic study of lipases A and B from Candida rugosa in the hydrolysis of lipid P-nitrophenyl esters in mixed micelles with triton X-100. Biochimica et Biophysica Acta, v. 1243, no. 1, p. 15-24, 1995. https://doi.org/10.1016/0304-4165(94) 00112-B

Reetz, M. T. Lipases as practical biocatalysts. Current Opinion in Chemical Biology, v. 6, no. 2, p. 145-150, 2002. https://doi.org/ 10.1016/S1367-5931(02)00297-1

Romo-Sanchez, S.; Alves-Baffi, M.; ArevaloVillena, M.; Ubeda-Iranzo, J.; Briones-Perez, A. Yeast biodiversity from oleic ecosystems: Study of their biotechnological properties. Food Microbiology, v. 27, no. 4, p. 487-492, 2010. https://doi.org/10.1016/j.fm.2009. 12.009

Sangiliyandi, G.; Gunasekaran, P. Extracellular lipase producing Bacillus licheniformis from an oil mill refinery effluent. Indian Journal Microbiology, v. 36, p. 109-110, 1996.

Selvamohan, T.; Ramadas, V.; Sathya, T. A. Optimization of lipase enzyme activity produced by Bacillus amyloliquefaciens isolated from rock lobster Panlirus homarus. International Journal of Modern Engineering and Research Technology, v. 2, no. 6, p. 4231-4234, 2012. Available from: <http://www.ijmer.com/papers/Vol2_ Issue6/BV2642314234.pdf>. Accessed on: Apr. 27, 2018.

Shariff, F. M.; Leow, T. C.; Murkhed, A. D.; Salleh, A. N.; Basri, M.; Rahman, R. Production of L2 lipase by Bacillus sp. strain 12: Nutritional and physical factors. Journal of Microbiology and Biotechnology, v. 47, no. 5, p. 406-412, 2007. https://doi.org/ 10.1002/jobm.200610275

Sharma, A. K.; Sharma, V.; Saxena, J. Review on applications of microbial lipases. International Journal of Biotech Trends and Technology, v. 6, no. 4, p. 1-5, 2016.
https://doi.org/10.14445/22490183/IJBTTV19P601

Shelatkarm, T.; Padalia, U. Lipase: An overview and its industrial applications. International Journal of Engineering Science, v. 6, no. 10, 2016. Available from: <http://ijesc.org/upload/d23f1f0af590d9bcc 02bdc6e229771c2.Lipase\%20An\%200vervi ew\%20and\%20Its\%20Industrial\%20Applica tions.pdf>. Accessed on: Apr. 27, 2018.

Shirazi, S. H.; Rahman, S. R.; Rahman, M. M. Production of extracellular lipases by Saccharomyces cerevisiae. World Journal of Microbiology and Biotechnology, v. 14, no. 4, p.595-597, 1998. https://doi.org/ 10.1023/A:1008868905587

Srivastava, A.; Prasad, R. Triglycerides based diesel fuels. Renewable and Sustainable Energy Reviews, v. 4, no. 2, p. 111-133, 2000. https://doi.org/10.1016/S1364-0321 (99)00013-1

Sumita, T. Lipases, its sources, properties and applications: A review. International Journal of Scientific and Engineering Research, v. 3, no. 7, p. 1-29, 2000. Available from: <https://www.ijser.org/research paper\Lipases-its-sources-Properties-andApplications-A-Review.pdf $>$. Accessed on: Apr. 27, 2018.

Sztajer, H.; Maliszewska, I.; Wieczorek, J. Production of exogenous lipase by bacteria, fungi and actinomycetes. Enzyme Microbial Technology, v. 10, no. 8, p. 492-497, 1998. https://doi.org/10.1016/0141-0229(88) 90027-0

Thakur, S. Lipases, its sources, properties and applications: A review. International Journal of Scientific and Engineering Research, v. 3, no. 7, p.771-799, 2012. Available from: <https://www.ijser.org/ viewPaperDetail.aspx?I016301>. Accessed on: Apr. 27, 2018.

Turner, C.; Persson, M.; Mathiasson, L.; Adlercreutz, P.; King, J. W. Lipase-catalyzed reactions in organic and super-critical solvents: Application to fat-soluble vitamin determination in milk powder and infant formula. Enzyme Microbial Technology, v. 29, no. 2/3, p.111-121, 2001. https://doi.org/10.1016/S0141-0229(01) 00359-3

Vakhlu, J.; Kour, A. Yeast lipases: Enzyme purification, biochemical properties and gene cloning. Electronic Journal of Biotechnology, v. 9, no. 1, 2006. 
https://doi.org/10.2225/vol9-issue1fulltext-9

Vaseghi, Z.; Najafpour, G. D. An investigation on lipase production from soybean meal and sugarcane bagasse in solid state fermentation using Rhizopus oryzae. International Journal of Engineering, v. 27, no. 2, p. 171176, 2014. Available from: <http://www.ije.ir/Vol27/No2/B/11572.pdf>. Accessed on: Apr. 27, 2018.

Verma, M. L.; Kanwar, S. S. Properties and application of poly(methacrylic acid-cododecyl-methacrylate-cl-N,N-methylene bisacrylamide) hydrogel immobilized Bacillus cereus MTCC 8372 lipase for the synthesis of geranyl acetate. Journal of Applied Polymer Science, v. 110, no. 2, p. 837-846, 2008. https://doi.org/10.1002/ app.28539
Verma, N.; Thakur, S.; Bhatt, A. K. Microbial lipases: Industrial applications and properties (a review). International Research Journal of Biological Sciences, v. 1, no. 8, p. 88-92, 2012. Available from: <http://www.isca.in/IJBS/Archive/v1/i8/15 .ISCA-IRJBS-2012-180.pdf>. Accessed on: Apr. 27, 2018.

Volpato, G.; Rodrigues, R. C.; Heck, J. X.; Ayub, M. A. Z. Production of organic solvent tolerant lipase by Staphylococcus caseolyticus EX17 using raw glycerol as substrate. Journal of Chemical Technology and Biotechnology, v. 83, no. 6, p. 821-828, 2008. https://doi.org/10.1002/jctb.1875 